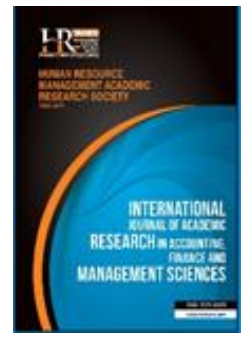

International Journal of Academic Research in Accounting, Finance and Management Sciences

Vol. 8, No.3, July 2018, pp. 238-254

E-ISSN: 2225-8329, P-ISSN: 2308-0337

(C) 2018 HRMARS

www.hrmars.com

To cite this article: Zulfadhli (2018). Determination of Industrial Competitiveness on Manufacturing Industry Growth in Palembang City, International Journal of Academic Research in Accounting, Finance and Management Sciences $8(3): 238-254$.

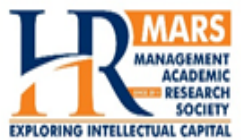

http://dx.doi.org/10.6007/IJARAFMS/v8-i3/4828 (DOI: 10.6007/IJARAFMS/v8-i3/4828)

\title{
Determination of Industrial Competitiveness on Manufacturing Industry Growth in Palembang City
}

ZULFADHLI

Department of Management Economics Tamansiswa, University Palembang - South Sumatra, Indonesia, E-mail: hertatilesi@yahoo.co.id

\begin{abstract}
The purpose of this study is to determine the determinants of industrial competitiveness that affect the growth of manufacturing industries in Indonesia. So that there is a paradigm shift in the business climate that surrenders the decision mechanism entirely to the market and then emerges competition in the business world that is increasingly tight with all the risks. Various products and services from within and outside the country can easily be found side by side, ready to compete with each other. With the rapid changes and increasingly fierce competition, only companies that have competitiveness will be able to survive. Whereas companies that do not have competitiveness will automatically "fade" because they cannot compete with other companies. This study shows that the determinants of competitiveness affect the growth of manufacturing industry in Indonesia significantly.

Key words Industrial competitiveness, industrial growth

Received: 25 Sept $2018 \quad$ C The Authors 2018

Revised: 15 Oct 2018 Published by Human Resource Management Academic Research Society (www.hrmars.com)

Accepted: 25 Oct 2018 This article is published under the Creative Commons Attribution (CC BY 4.0) license. Anyone may Published Online: 2 Nov 2018 reproduce, distribute, translate and create derivative works of this article (for both commercial and noncommercial purposes), subject to full attribution to the original publication and authors. The full terms of this license may be seen at: http://creativecommons.org/licences/by/4.0/legalcode
\end{abstract}

\section{Introduction}

Business organizations are becoming increasingly competitive and changing rapidly. Companies are required to always develop at all times. In the era of free trade, it has become a necessity for every company to survive tight competition (Suryono, 1999). Every company cannot be quickly satisfied with the achievements it has achieved, more than that, efforts are still needed so that the achievements that have been achieved can be maintained and improved over time. Likewise with the market, where there has been a paradigm shift in the business climate that surrenders the decision mechanism entirely to the market so that business competition emerges that is increasingly tight with all the risks. Various products and services from within and outside the country can easily be found side by side, ready to compete with each other. With the rapid changes and increasingly fierce competition, only companies that have competitiveness will be able to survive. Whereas companies that do not have competitiveness will automatically "fade" because they cannot compete with other companies.

The concept of competitiveness comes from the concept of comparative advantage. According to Schiller (1997) comparative advantage is the ability of a company or country to produce specific goods at low opportunity costs compared to other companies or countries. Meanwhile, Dunford et al. (2000) say that the concept of competitiveness is the ability of an industry to compete in the long run, which depends not only on product quality and low costs, but more than that based also on the ability to follow, determine, and evolve the market. 
Chacholiades (1990) says that a company or country is said to have comparative advantage when a company or country has a higher advantage in its commodities, and has comparative losses when its superiority is low in its commodities. Tambunan (2001) states that the average RCA value above 1 indicates a high level of competitiveness. Whereas, the average RCA value below 1 indicates a low level of competitiveness. Regarding the context above, the manufacturing industry sub-sector is one of the most stringent sub-sectors to feel business competition. Such conditions, increasingly demanding manufacturing companies to produce high-quality, competitive products and have various added values in accordance with changes in the world business environment.

Industry groups that have different competitiveness, namely: the first group consists of manufacturing industry sub-sectors that have an average RCA value above 1 , showing sub-sectors that have high competitiveness, such as the textile industry, leather goods and apparel sub-sector. (ISIC 32); other processing industry sub-sectors (ISIC 39); wood goods and forest products industry sub-sector (ISIC 33); and industrial sub-sectors of basic metals, iron and steel (ISIC 37). Based on the description above, there are currently 5 (five) sub-sectors that have RCA values below 1, indicating the low level of competitiveness owned by the sub-sector in the context of export activities and international trade. Meanwhile, judging from the competitiveness of Indonesian manufacturing products in the framework of international trade, based on the publication released by UNIDO (United Nations Industrial Development Organization) based on the 102-nation Growth Competitiveness Index, Indonesia shows relatively low competitiveness, even still far below neighboring countries, such as Malaysia, Singapore and Thailand. Indonesia's competitiveness is only slightly superior to the Philippines.

According to Tambunan (2001), the size of the competitiveness of industrial sub-sectors in the context of export activities is generally influenced by the level of prices, technology, capital, quality workforce, growth in manufacturing industry and government policies. One factor that influences competitiveness is price. The price level will be determined by the amount of costs incurred by the company. A company if it has a lower cost compared to competitors then it has competitiveness or advantages in terms of cost. This happens in sales where companies that have competitiveness or cost advantages will sell at lower prices compared to its competitors. Consequently, consumers are expected to prefer companies with lower prices than higher prices.

Porter (1994) said that cost advantages occur when the cumulative costs incurred by companies in carrying out value activities are lower than the cumulative costs of their competitors. Thus, if the costs are low, the company can sell at a lower price. Besides prices, mastery in technology is also a determining factor for the competitiveness of a country's export products, especially in supporting the comparative advantage of the country's export commodities. The reality shows that technological progress tends to be the dominant production factor in the pattern of export development. The use of new technology in production activities will increase the competitive advantage of these products. The use of high technology in machinery, process, communication, information, promotion and distribution that has been tested for reliability will improve the competitiveness of these products in the international market.

The existence of technological changes made by several industries, namely the change from traditional technology to advanced technology, has encouraged an increase in the competitiveness of export products produced by these industries. Mastery of more modern technology, will be able to improve product quality and create more competitive product prices. Technology influences competitive advantage if the technology has a significant role in determining the position of relative costs or relative differentiation.

Capital factors also play a role in influencing competitiveness. According to Cooper (1995), capital factors play an important role in the operation of all business activities and form competitiveness. The availability and capability of capital in certain industries will have an impact on the competitiveness of the industry concerned. Capital is needed to supplement the ever-increasing human resources so that capital accumulation is something that is inevitable to expand production, bring in new technology, bring in skilled labor and increase output.

Besides prices, technology and capital, the variable quality workforce is also an important factor in determining the competitiveness of a country's industrial products for export purposes. As has been proven by the countries of South Korea, Taiwan, Singapore, Hong Kong and Japan. Although they do not have 
abundant and diverse natural resources (SDA), but they have succeeded in developing and enhancing the competitiveness of their export products because of the support of a qualified workforce. Government policy in influencing competitiveness and trade international also cannot be denied. The government as a regulator can function to provide the principles of an authoritarian government bureaucracy with strict administrative control to protect the domestic market and local industries from foreign products and newcomers. The role of the government in making regulations is expected to be able to push the industry towards a better stage, in the end directly or indirectly, it will direct industries to produce competitiveness of their products, so that they can compete not only in the local market, more than that, they can compete in a more competitive global market (Araujo, 1999).

To improve industrial competitiveness is the growth of the industry itself. Growing industries increase the accumulation of output in their production and reduce the average cost, due to the spillover effect so that the product price becomes lower. In addition, industries that are growing experience learning that results in increased efficiency. With the learning process, the average cost decreases with increasing production. Thus, the growth of an industry can explain the increasing competitiveness of the industry (Besanko et.al., 1996).

The rate of output growth for each manufacturing industry before and after the crisis, where the economic crisis has been the cause of the decline in the growth of the manufacturing industry subsector where the average growth of the manufacturing sub-sector before the crisis was 7.97 percent, which experienced a decline in industrial growth -0.50 percent in the period after the crisis. This shows that most of the sub-sectors included in the manufacturing industry group experienced a decline in output in the period after the crisis.

\section{Factors that Determine Competitiveness}

\section{a. Human Resources Factors}

Human resources have a strategic position in driving the economic progress of a nation. The availability of human resources will potentially function as an element of driving economic progress and competitiveness of a nation. Nations that have relatively abundant human resources will have relatively superior competitiveness compared to countries that lack human resources. Even so, not a few countries have relatively abundant human resources but do not have the ability to push for economic progress, and do not have competitiveness. Not a few countries also lack human resources relatively but are relatively fast and can compete in the global market.

Human resources are abundant but cannot compete, occur in most developing countries like Indonesia. If human resources are an element as a development agent, then as an actor must get attention for its development. Efforts to develop human resources in the era of globalization are very important because in the era of globalization faced with intense competition and unavoidable. Human resource development efforts must be able to adjust to technological developments that are as fast as they are today. Although this is not a simple job. Especially the transformation of the Indonesian economy from agrarian to industrial sector, must be carried out simultaneously with the transformation of its human resources.

Human resources as labor in the economic sector from agriculture to industry, because their expertise is limited to the agricultural sector, the strategy of developing human resources in Indonesia must refer to the problem of human resources as labor in this country. The World Bank in Yudo Suwasono and Endang (1993) suggests that the development of human resources (HR) is all activities in the fields of education and training, health, nutrition, decreased fertility, increased entrepreneurial skills, development and technology. In 1988, the World Bank expanded the notion of human resource development by incorporating new elements, namely: employment opportunities, a healthy environment, workplace development, free political life.

The United Nations Development Program (UNDP) based on its study has formulated new knowledge from human development which was published in its 1991 report stating that human development (human resource development) is a process of increasing people choice. people) and on the basis of the opportunity to create income and employment growth. Human development is a process of increasing human capacity, the process is concentrated evenly on increasing the formation of human abilities, through 
investment in human beings, and utilization of human capabilities, through the creation of a framework for participation to generate income and increase employment opportunities (Yudo Swasono and Endang, 1993).

Canadian International Development Agency (CIDA) stated about Human Resource Development (PSDM), published in McWhinney (1980) written by Yudo Swasono and Endang (1993): That the development of human resources as the core and target of development, which in the short term relating to education and training that is immediately useful to meet the needs of skilled, managerial and administrative workforce. The concept of human resource development (PSDM) and technology is the choice of many countries towards the era of industrialization. East Asian countries, such as Japan, South Korea, Taiwan and China (Hong Kong) and Singapore and Malaysia have been able to produce products that can compete in global markets. The competitiveness of a product cannot be separated from the ability of human resources in relation to the mastery of technology. Thus the role of human resources is significant to technological development.

Vincer and Cshultz in Anwar, Basri and Ikhsan (1995) say there is a strong enough positive relationship between the level of education (formal) that someone has with the individual's ability to learn during work (learning by doing), then it is said that education even the most basic that gives a person the ability to read, write and count, can certainly develop in his work. So that gradually the work occupied by someone can give knowledge to the person concerned. Leontief in Salvatore (1997) has conducted research using United States trade data in 1947 using a hypothesis based on the Heckscher-Ohlin (HO) theory model, saying that the United States would export capital-intensive commodities and import labor-intensive commodities (energy work), given the United States is scarce labor. Leontief's findings are very surprising because they contradict the Heckscher-Ohlin (H-O) theory.

However, Leontief did not directly reject the Heckscher-Ohlin theory. He did a review. Since 1947 US labor has had a productivity level three times higher than labor productivity in other countries. With Leontief's research, it turned out that the United States produced a lot with a lower labor capital ratio than imported goods. It is known that apparently the United States products are more labor-intensive when compared with imported products. The United States also tends to export goods that are technology intensive. This observation is in line with the position of the United States as a country that has high skills, with comparative advantages in sophisticated goods, many of which require the ability of superior scientists and engineers. This gives an indication that between human resources or skilled labor has a significant influence on productivity.

\section{b. Technology concept}

According to Ichary (2008), the word "technology" is philosophically related to the word engineer. The word engineering and engineer relates and comes from the word genie that comes from Latin which is synonymous with genius (intelligent) or talent (talent). In the initial definition it was realized that technology was related to humans as users or recipients of impacts. 'Technology' relates to 'culture', concerning applied science, engineering, institutions also concerning social, political, cultural and economic systems. Likewise technology is closely related to humans and various factors that influence human thought and action, individually and in groups.

Another philosophical definition can be seen from Romer (2001), which defines technology as written by Berg, namely Technology is a complex set of knowledge, ideas, and methods and is likely to be a variety of different activities, both intentional and accidental. While Khalil (2000), stated that technology 'is Technology can be defined as all the knowledge, products, processes, tools, methods, and systems are employed in the creation of goods or in providing services. The use of high technology in machinery, process, communication, information, promotion and distribution that has been tested for reliability will improve the competitiveness of these products in the international market. The development of high technology must be followed by the ability of knowledge from industry players to be able to follow and apply it. 


\section{b. Technology Measurement}

Some methods of measuring technology, which are generally used in economics, are:

1. Total Factor Productivity: using the Cobb-Douglas model, to obtain a constant A or called Total Factor Productivity, which are all the factors inherent in technology in the process of output growth or not attached on non-technological factors (disembodied). Constant A shows the influence of technology in a production function in converting all inputs (production factors) into a number of outputs (Berg, 2000).

2. Cost Function: measurement of technology with a cost approach is based on an understanding of the production cost structure (Perez, 2001). In this approach, it can be known how efficient the output can be produced with certain inputs. Costs are seen as a response to the technology device (technoware) used and all conditions that affect the production process.

3. Coefficient of Leontief Technology: measurement of technology using the Leontief Technology coefficient approach is obtained from the Leontief Input-Output table in the form of a ratio of intermediate input between economic sectors. Input costs that are formed are also a response to the use and substitution of production factors in order to produce certain output values. The advantage of using technology size with this leontief technology coefficient is its ability to identify technology actors in a relatively detailed and complex inter-sector sub-sector, while having the ability to generalize its effects on economic growth (Drejer, 1999).

4. Technology Index: uses several indicators that are considered to be able to describe a level of technology, such as the ratio of spending on Research and Development (R \& D) or Research and Development to GDP, the ratio of exports of high-tech products, the ratio of labor in the field of exact science and engineering, the ratio workers who work in the field of $R \& D$, the ratio of computers per population, the number of technology works that are granted patent rights and so on as the World Human Development Report (2001).

5. Capital ratio to labor (K/L); the high and low technology used by an industry can be illustrated through the comparison of capital and labor. According to neo-classical theory, the ratio of production capital can easily change, because of the relationship between labor and capital. In creating a certain amount of production different capital can be used with the help of workers whose numbers are different as needed. If capital is used more, then less labor is needed. Conversely, if capital is limited, more labor is used (Berg, 2001).

\section{c. Technology and Competitiveness}

Technology can affect cost or differentiation and competitive advantage by changing or influencing all cost determinants or other uniqueness (Porter, 1994). Technological developments can increase or decrease economies of scale, open up possibilities for various relationships that were previously impossible to occur, create opportunities to achieve excellence in timing, and influence almost all determinants of costs or other uniqueness. So the company can use its development, or to become the first or perhaps the only company that utilizes certain determinants.

Todaro (2000) suggests that important economic growth factors in any society are: (1) capital accumulation, including all new investments in the form of land, physical equipment and human resources, (2) population development, growth in the workforce although late, (3) technological progress. Capital accumulation will succeed if several parts/proportions of income will be saved and invested to increase output. Meier stated in the Asian Economic Journal (1999) that the contribution of capital accumulation to growth was measured by its contribution to the multiplication of national income from capital. Mankiw (2000) presented the experience after the Second World War, the Japanese and German economies experienced rapid growth. Solow stated in Mankiw (2000) about the relationship between savings and economic growth. High savings leads to faster growth.

Nicholson (1995) said that the capital stock of an economy is the total number of machines, buildings, and non-labor manufacturing sources that exist at a time, the company's wealth (assets) reflects the share of economic output in the past which is not consumed, but is set aside for future production uses. Furthermore Tucker (1998) states that: Investment means that an economy is producing and accumulating capital. Investment consists of factories, machines, and inventories (capital) produced in the present that are used to shift the production possibilities curve outward in the future. 


\section{d. Price Factor}

Mankiw (2000), states that the imperfect information model states that if prices exceed the expected price, suppliers increase their output. The short-run aggregate supply curve is upward sloping, the stickyprice model, emphasizing that companies do not instantly adjust the price they set in response to changes in demand. Sometimes prices are set by long-term contracts between the company and the customer. Even without a formal agreement, companies can maintain prices so as not to bother their regular customers with frequent prices changing. Sometimes prices are difficult to change because of the market structure, once the company prints and distributes catalogs or lists of prices, it is expensive to change prices.

To see how far price rigidity can help explain the upward sloping aggregate supply curve, we first consider the pricing decisions of individual companies and then unify the decisions of many companies to explain the overall economic behavior. Remember that this model encourages us to ignore competitive assumptions. Competitively competitive companies are price takers rather than price setters. If we want to pay attention to how companies set prices, it is reasonable to assume that these companies have at least monopoly control over the prices they charge.

\section{Government Policy Factors}

To improve the competitiveness of a nation, both domestic competitiveness and international competitiveness require a public policy (government) that will solve complex problems. Public policy is defined as a series of actions (actions) or silence (in action) of public authorities (government) to solve a problem. Government policies and national benefits that influence important factors, namely the four factors that make up the superiority of national "diamond" competing systems are the best approaches. While monetary, fiscal, education and making regulations and other policies are not enough. The role of government with its policies can be influenced and influence the four categories of national attributes both positively and negatively. The influence of government policies is as follows:

\section{Government Influence on Factor Conditions}

The government is very influential on the conditions of factors that encourage companies to improve the quality of their competitive advantage over time. The conditions of these factors include skilled human resources (HR), basic science, economic information, and infrastructure. Whereas the rate of upgrading in the national economy is determined by the quantity and quality of factors.

\section{Government influence on Demand Conditions}

The main objective of the policy in terms of demand is to improve the quality of domestic demand. This is due to the quality of demand holding a major role in the upgrading process. Government policy greatly influences the way companies are created, organized, managed, setting goals, and how the company competes. The most important government policy to improve the competitiveness of a nation requires two types of policies, namely the government's primary policy and government support policies (Kotler). e. Government Primary Policy

To improve the nation's competitiveness, policy makers must formulate their primary policies to compete and cooperate with other countries.f. Government Support Policy Some supporting policies are needed to enable the government's primary policy to work efficiently.g. Competitiveness. The level of competitiveness of a country's or industry's export commodities can be analyzed by various methods or measured by a number of indicators, one of which is to use Revealed Comparative Advantage (RCA). The results of the study show that in the early 1990s the level of export competitiveness of Indonesian agricultural commodities was high with the overall RCA index 50 percent more than 1.

\section{Empirical Study}

Many studies have been carried out related to competitiveness, both national competitiveness and industry, especially their influence on industrial growth. Some previous studies on competitiveness can be stated as follows: Empirical studies that have been conducted are related to competitiveness models, especially studies that estimate the factors that determine competitiveness. Some of them can be seen 
from the empirical studies of Greaker (2004), Silva and Rodrigues (2005), Sanjaya Lall (2003), Reiljan et al. (2000), Thurow (1992), and empirical studies from Breschi and Palma (2001).

Greaker (2004) examines the relationship between industrial competitiveness and technological inventions and environmental policies in companies in Norway. The test results conclude that the discovery of new technologies that can reduce pollution and policies in the environmental field (such as the application of tightened emission limits and the provision of environmental subsidies) can improve the competitiveness of corporate products. Silva and Rodrigues (2005) examine competitiveness and private public partnerships. In its research on 131 alliances between 2000 and 2003, competitiveness was defined as the ability of economic units (companies, regions, and countries) to increase their share in global markets. According to them, a company that has stated to participate in international competition, of course must increase efficiency through increasing organizational efficiency and their innovation activities.

In the calculation, cluster analysis is used, namely by grouping companies in 5 (five) clusters, with the number of companies in each cluster 1 to 5 respectively $3,66,32,11$, and 19 companies. The results of his research indicate that the competitiveness factors above, which consist of primary factors, typical public goods, collective entrepreneurship and global market significantly, influence the competitiveness of a company in the global market. Sanjaya Lall (2003) argues that the main causes that can drive increased industrial competitiveness in developing countries are the ability to utilize technology, exchange rates and government policies that can cover the company's business activities. These three variables have a positive and significant effect on industrial competitiveness.

In the research of Reiljan et al. (2000) can be explored about the role of technical and technological development, rational costs (ratio of quality to price), and political economic conditions in influencing industrial competitiveness. Meanwhile Thurow (1992) argues that natural sources, modern technology, price levels, large capital, and various skills possessed by the workforce (quality of labor) are the keys to success that can affect the competitiveness of export products from certain industries in developing countries. Meanwhile, in the study of Breschi and Palma (2001), it was stated that the variables of innovation, patents, exchange rates and technology localization are variables that affect the competitiveness of export products in 93 provinces in Italy. Using the time series data for the period 1988 to 1995, empirical evidence found that innovation, patents, and technology localization had an effect on the competitiveness of export products, which was reflected by their increasing exports during that period.

Empirical studies of the factors that influence power can also be seen in the research of Mulatu et al. (2001), Cooper (1995), Araujo (1999), Dunford et al. (2000), Godin (2004), Pearce (2006), Narula (2006), Ernst (2006), Reddy (2006). In the research of Mulatu et al. (2001), there is a role for environmental regulation in influencing competitiveness and international trade (2001). In explaining the impact of environmental regulation on competitiveness, Mulatu et al. are using three approaches, namely the exploratory approach, the Leontief approach, and the econometric approach. Conclusions from the results of his research can be stated that based on the three approaches it is known that environmental regulation has a significant influence in influencing competitiveness and international trade.

Meanwhile, according to Cooper (1995) an economist from the Netherlands argued that technology is the main source in shaping export competitiveness, in addition to capital, exchange rates and labor. According to him, the change in technology carried out by several industries, namely the change from traditional technology to advanced technology, has encouraged an increase in the competitiveness of export products produced by these industries. Mastery of more modern technology will be able to improve product quality and create more competitive product prices. The results of his research suggest that the industrial sector immediately change and improve their technology so that the export products they produce can compete not only in the domestic market, but also in the international market.

In Araujo's writings (1999), it can be seen further how important changes in attitudes of policy makers during the formulation of regulations and industrial growth in order to improve industrial competitiveness in Portugal. In the previous few years, the authority of policy makers in the industry in the country was under the auspices of the Directorate General of Industry (GDI). When it was founded around 1930, the Directorate controlled the industrial sector. GDI is functioned to provide the principles of an authoritarian government bureaucracy, with strict administrative controls to protect the domestic market and local industries from foreign products and newcomers. 
According to Araujo (1999), in order to increase the competitiveness of local industries, a shift in policy formulation is needed, which has been done more often without involving other elements outside the government bureaucracy. Furthermore Araujo suggested the need for openness and involved other competent parties in formulating policies in the industrial sector, which included the need to involve other parties outside the government, such as companies, universities, and research organizations. According to him, the role of the government in making regulations that are able to push the industry towards a better stage, ultimately directly or indirectly.

Meanwhile, UNIDO (United Nations Industrial Development Organization, 2003) argued that the main structures that drive industrial competitiveness include foreign direct investment (FDI), technology, local Research and Development (R \& D), expertise, licenses and physical infrastructure. Based on UNIDO's research in 6 countries, namely the Republic of Korea, Taiwan, Singapore, Malaysia, Thailand, and the Philippines, it can be proven that these variables are significant in influencing industrial competitiveness. FDI has encouraged the transfer of various things from the country of origin to the destination country of foreign investment. These transfers are not only financial transfers, but are also followed by technology, resources, experts, culture, information, and others. With the presence of FDI, the investment destination countries can improve the competitiveness of their industries. Likewise with technology, local R \& $D$, licenses, and physical infrastructure, it has also become a contributing factor in increasing industrial competitiveness.

The importance of technology and R \& D in improving industrial competitiveness can also be seen in the writings of Godin (2004), an economist from Canada. According to him, technology, prices and R \& D contribute quite centrally in shaping industrial competitiveness. The use of high technology and R \& $D$ activities in producing more efficient products can encourage companies to be more innovative in creating quality new products, creating new markets, expanding businesses, and using more productive resources, so companies can increase profits in the market shar. This opinion is confirmed by Pearce (2006), Narula (2006), Ernst (2006), Reddy (2006) that technology, R \& D, price and innovation are the main variables for the industry in shaping the competitiveness of their products in the global market.

While other empirical studies that estimate the effect of competitiveness on industrial growth, as can be seen from the empirical study of Lengyel (2003), which in his research on industrial growth and competitiveness in the Hungarian country, revealed that industrial competitiveness can affect industrial growth in a country. The higher the competitiveness of industrial products, it will encourage an increase in industrial output in the form of production, as a result of increased exports of industrial products in the international market.

Other empirical studies are sourced from Ippey (2001), Simons (2003), Fagerberg et al. (2004), Ohno and Imaoka (2004) and Marzabal (2004). Ippey (2001) economy from Japan, in his empirical study of industrial growth and product competitiveness revealed the importance of competitiveness, labor, trade policy in the field of tariffs on industrial growth in Japan for the period 1970-1999. The results show that all variables have a positive influence on industrial growth in Japan. Simons (2003), who examined the competitiveness and growth of industry in Germany during the 1990-2002 period, found empirical evidence that the variables that influence industrial growth are the competitiveness of products, infrastructure, labor and industrial structures. Fagerberg, Knell, and Srholec (2004) in research on national competitiveness in 49 countries included in the ECE region (including New EU members and developing countries in Asia and Latin America). Data used between 1993-2001. In his research stated that some aspects of competitiveness, which consists of technology, capital, price, labor and demand are relatively variables that can affect industrial growth in a country.

Meanwhile, in the research of Ohno and Imaoka (2004), which examined the industrial growth in both countries (dual industry), namely Korea and Taiwan in the period 1961-2000, there was empirical evidence that industrial growth in both countries was determined by the variable intensity factor, ratio export-import, industrial structure and capital. All variables have an effect on industrial growth at a significance level (alpha) of $1 \%$.

Marzabal (2004), as he wrote about the competitiveness and growth of regional industries in the European Union for the data period of 1995-2002, tried to analyze the relationship between competitiveness and industrial growth. In this study, competitiveness is measured using a unit of labor 
costs. Furthermore, the analysis unit is divided into three regional groups, namely the most competitive region, the intermediate competitive region and the less competitive region. In the results of his research found some empirical evidence of the relationship between different patterns of competitiveness against industrial growth in the region. In the most competitive region, competitiveness has a positive influence on industrial growth. Whereas in the intermediate competitive region and the less competitive region, competitiveness has a negative influence on industrial growth.

The results of research on industrial growth can also be seen in the empirical study of Athukorala and Jayasuriya (2004), Dutta and Ahmed (2006), Hirway and Shah (2006), Braun, Briones and Johnson (2007), Greasley and Oxley (2007) and Suslova and Volchkova (2007), the explanation is as follows:

1. Athukorala and Jayasuriya (2004) in their research which examined industrial growth in Sri Lanka in the period 1970-2001. The results of his research show that industrial growth in Sri Lanka is determined by capital, labor and tariff policies. Capital variables have a positive influence on industrial growth, while labor and tariff setting policies negatively affect industrial growth.

2. Empirical studies of Dutta and Ahmed (2006) on trade policy and industrial growth in Pakistan for the period 1973-1995, examined several variables that were strongly suspected of influencing industrial growth, including stock capital (capital), labor, real exports and tariff rates import. By using cointegration analysis, it is known that capital stock and real exports have a positive and statistically significant effect, while the labor and import tariff variables have a negative and statistically significant effect.

3. Hirway and Shah (2006), in the empirical analysis of the determinants of industrial growth in India for the period 1984-2004. The variables used are competitiveness, capital, labor, intensity factors and import tariffs. The results obtained are that competitiveness, capital and intensity factors have a positive effect on industrial growth, while labor and import tariff variables have a negative influence on industrial growth in India.

4. The empirical study of Suslova and Volchkova (2007) on 24 developing countries in assessing the linkages of capital and industrial structure with growth in developing countries in the period 1974-2005. The conclusion from the results of his study is that industrial growth in developing countries is influenced by variable capital availability and industrial structure. Variable capital availability and industrial structure have a positive and significant effect on industrial growth in developing countries.

5. Greasley and Oxley (2007), who examined the competitiveness and growth of industry in the United Kingdom (UK) for the period 1980-2005, found empirical evidence that there were 4 (four) variables that had an influence on industrial growth, namely product competitiveness, structure industry, technology and capital. The results show that all variables have a positive and statistically significant influence on industrial growth in the UK.

6. Braun, Briones and Johnson (2007), which examines the competitiveness and industrial growth of the 1975-2005 period in 8 (eight) Latin American countries, such as; Brazil, Peru, Bolivia, Argentina, Chile, Paraguay, Uruguay and Venezuela, found empirical evidence that the variables of competitiveness, industrial structure, infrastructure and technology have a positive and significant impact on industrial growth in the eight countries.

\section{Framework}

Dong-Sung Cho (2000: 138) states that the concept of international competitiveness, which according to him does not only depend on the problem of labor, capital, many natural resources, and low prices. This resource is only part of many determinants. Cho provides a definition of international competitiveness of a national industry is an industry that has a superior market through high profit and constant growth compared to its competitors. Countries that have international competitiveness must have many types of industries with strong competitiveness, not with only one or two successful industries (Hertati, 2015). Next is Adam Smith (Salvatore, 1997) with the model of absolute excellence as a justification for international trade. According to this theory, a country must export a commodity that can be produced at a lower cost than what other countries can do. Instead the country must import a commodity that can only be produced at a relatively higher cost compared to other countries. Thus, global efficiency can be improved through free trade. He said that if trade is not restricted and done freely, then each country can specialize in products that have comparative advantages for him (Hertati, 2015). Every 
source is transferred to an efficient industry because the state cannot fight in an inefficient industry (Hertati, 2016).

In subsequent developments, based on the theory of comparative advantage, David Ricardo said that absolute costs were irrelevant. The theory of comparative advantage he put forward based on the theory of relative costs as the basis for the occurrence of trade between countries. Like Adam Smith, David Ricardo ignored the functions of land and capital, and only paid attention to labor factors. The theory of comparative advantage states that although a country is able to produce all goods at a lower price than other countries, trade can still benefit both countries namely based on comparative costs. Ricardo's theory of comparative advantage only emphasizes the value of labor factors that determine the value of labor productivity where it is efficiency in the use of labor as an indicator of the comparative advantage of a commodity.

The global era of the theory of comparative advantage is not enough to solve the problem of trade between countries, because it no longer relies on comparative advantage by relying on natural resources and labor internally. The advancement of science and technology will encourage trade between countries which is the core of the theory of competitive advantage. The competitive advantage theory of Porter (1994) says that in an era of global competition a country that has the ability to compete in international markets, if it has four determinants, namely the factor of resource conditions demand factors.

In the current era of globalization, there is a tendency that the level of competitiveness of national industries for export products is no longer determined only by price differences, but also determined by other aspects that are even more dominant than prices, such as quality, after-sales service and so on. Besides these aspects, according to Tambunan (2001), the level of national industry competitiveness can also be influenced by product quality, price, quality of human resources, technology and government policies. Some experts in economics, such as Krugman (1993), Daniels and Radebaugh (1989), Best (1990), Grossman and Helpman (1993) and Porter (1994), have long said that the competitiveness of industrial products for export from a country is determined primarily by: technology, high level of efficiency/ productivity in the production process, quality of goods produced, labor with skills/education levels, economies of scale, innovation, product differentiation, capital and adequate facilities and infrastructure, and networks distribution both at home and abroad.

In the era of industrialization, especially in the global market as it is today, high quality human resources are one of the important factors in determining the competitiveness of a country's industrial products for export purposes. As has been proven by the countries of South Korea, Taiwan, Singapore, Hong Kong and Japan. Even though they do not have abundant and diverse natural resources, they have succeeded in developing and enhancing the competitiveness of their export products because of quality human resources support. Quality human resources who have the spirit of entrepreneurship can support increased competitiveness of export products. Tambunan (2001) argues that a high level of entrepreneurship is an important factor in determining the level of competitiveness of a country in global trade. The role of quality human resources in improving competitiveness can also be seen in the research of Thurow (1992), Cooper (1995), Dunford et al. (2000).

Besides human resources, mastery in the technology sector also determines the competitiveness of a country's export products, especially in supporting the comparative advantage of the country's export commodities. Technology influences competitive advantage if the technology has a significant role in determining the position of relative costs or relative differentiation. Given the technological factors contained in each value activity and play a role in realizing the linkages between various activities, technology can have a major influence on costs and differentiation. The technology used in a value activity is often the result of other determinants, such as economies of scale, timing and relationships (Hertati, 2015). Therefore, a company that has better technological facilities than its competitors, the company will have a competitive advantage in its business activities.

In addition to influencing costs or differentiation, technology can influence competitive advantage by changing or influencing all cost determinants or other uniqueness (Porter, 1994). Technological developments can increase or decrease economies of scale, open up possibilities for various relationships that were previously impossible to occur, create opportunities to achieve excellence in timing, and 
influence almost all determinants of costs or other uniqueness. So the company can use its development, or to become the first or perhaps the only company that utilizes certain determinants (Hertati, 2015).

The role of technology in supporting and improving competitiveness as can also be seen in several empirical studies, including the results of research by Thurow (1992), Cooper (1995), Reiljan et al. (2000), Dunford et al. (2000) , Breschi and Palma (2001), Sanjaya Lall (2003), Godin (2004), Pearce (2006), Narula (2006), Ernst (2006) and Reddy (2006). Furthermore, the increase in exports and the competitiveness of export products is not enough only with the ability of human resources and technology. In addition, there are other factors that can encourage increased exports, including; capital, product prices, exchange rates and government policies (Irsad Arifandi, 2002).

Capital factors will shape competitiveness and increase exports. Whatever form of business without capital, a business will not run. Capital plays an important role in the operation of all business activities. The availability and capability of capital in the national industry will have an impact on the competitiveness of the industry concerned. The greater the capital of a company, the greater the company's ability to develop its business and the greater the company's support in forming quality products that can compete with other products. The role of capital in influencing competitiveness, as can be traced from the results of Cooper's (1995) research. The role of capital in supporting and enhancing competitiveness can also be seen in the results of Thurow's (1992) empirical study which said that capital is one of the factors that influence industrial competitiveness.

Furthermore Darmansyah (1986) research analyzed the role of prices in international trade. The results of the analysis concluded that the competitiveness of an export product is influenced by the price factor. Low prices reflect the low production costs that accompany the product. According to Kuntz and Clow (1998) that high prices show high quality, and vice versa low prices show low quality. Other research on the effect of prices in order to improve competitiveness can be seen from the results of Thurow (1992), Reiljan, Hinrikus, and Ivanov (2000), Dunford, Louri, and Rosenstock (2000).

According to Porter (1994) competitiveness is determined by competitive advantage in producing products at low costs. The lower and reasonable the product price of a country, the more competitive the product will be (Hertati, 2015). Macrae (1996) states that buyers, both new and old, use prices as a selection of the quality image of a brand. Meanwhile, according to Etzel et al. (1997), "price is the amount of money or other items with utility needed to acquire a product. Recall that the utility is an attribute with the potential to satisfy wants. While Stanton (1991) suggests that the price of a product will affect the competitiveness of the product on the market. Pricing for a product is a factor that influences the company's market share, because prices affect the competitive position of the competition, and increase the company's profit. Afiff (1994), states that there are three possibilities for price policy, namely; (1) pricing above rival prices, (2) fixing prices below rival prices, and (3) following rival prices so that subscribers do not switch. Meanwhile, according to Sukirno (2000), stating high prices reduce demand and the lower the price the more demand.

Cravens (1996) suggests that competitive advantage is an advantage over competitors that is obtained by conveying greater customer value through cheaper prices or by providing more benefits in accordance with higher pricing. Competitiveness is the ability of the producer to produce a commodity of good quality, the production costs are quite low and have a price that can compete in the international market so that producers obtain profits that can be used to maintain their production continuity (Hertati, 2015). The role of prices in supporting competitiveness can be seen in the results of the study; Thurow (1992), Godin (2004), Pearce (2006), Narula (2006), Ernst (2006) and Reddy (2006).

Other variables that affect competitiveness are exchange rates. In a trade perspective, a stronger and stronger exchange rate can increase the purchasing power of raw materials and capital goods, both domestic and foreign. With low production costs, the prices of export commodity products are more able to compete in foreign markets. Case and Fair (1999) says that a country's currency depreciation can serve as an export stimulus. According to Krugman and Obstfeld (2000), the occurrence of depreciation or devaluation tends to affect terms of trade. A depreciation or devaluation of the exchange rate will stimulate the competitiveness of export production. Devaluation or depreciation will tend to encourage the price of imported products to rise and the price of export products to fall in foreign currency. On the other hand, it increases the competitiveness of export products in foreign trade. 
With the increase in export value automatically increases RCA. In other words, changes in a country's currency exchange rate will affect the competitiveness of its industry. In the trade perspective, the weakening exchange rate can encourage an increase in the competitiveness of export products, so that the country's foreign exchange earnings from the export sector increase. However, a policy that weakens its exchange rate itself can be applied in certain corridors, moreover the goal is to encourage exports, and only in the long run the policy becomes less good and less effective if it continues to be implemented. An increase in exports which is solely from the exchange rate depreciation without being balanced by an increase in the competitiveness of its products, will only make other countries harmed and will not be an added value to their economy.

However, in the long run the country is unlikely to continuously weaken its exchange rate either by means of devaluation or depreciation based on market mechanisms, because it can disrupt other sectors. Moreover, if the export is made from raw materials and capital goods, the import content is high. The influence of the exchange rate on competitiveness as can also be seen in empirical studies from Cooper (1995) and Sanjaya Lall (2003). The next variable is government policy which also has an important role in increasing competitiveness. The government policy regarding the production of commodities, among others, is in the form of pricing policies for inputs and outputs. This is done so that producers are encouraged to use domestic resources intensively, so that the producers are expected to operate with higher added value than before.

Empirical studies that examine government policies related to competitiveness can be seen from the results of Araujo (1999), Sanjaya Lall (2003), Mulatu, Florax, and Withagen (2001). Growing industries increase the accumulation of output in its production and will reduce the average cost, due to the effects of spill over (Church, 2000), so that the product price becomes lower. With the learning process, the average cost decreases with increasing production (Besanko et.al., 1996). Therefore, the growth of an industry can explain the increasing competitiveness of the industry, as stated by Araujo (1999) in his empirical study. With the increasing competitiveness of industrial products for export purposes, these products will have high value in the eyes of buyers (Porter, 1994), so as to encourage the number of products exported. Increasing the competitiveness of manufactured industrial export products will affect the growth of the manufacturing industry.

Empirical studies of the influence of industrial competitiveness on industrial growth can be seen from the results of Ippey (2001), Lengyel (2003), Simon (2003), Fagerberg et al. (2004), Marzabal (2004), Hirway and Shah (2006), Greasley and Oxley (2007) and Braum et al. (2007), which reveal that industrial competitiveness can affect a country's industrial growth. Besides industrial competitiveness, industrial growth is also influenced by variables such as; industrial structure, capital (capital) and total labor supply, and other variables. According to Hasibuan (1993) the industrial structure is the nature of the demand and supply of goods and services that are influenced by the type of goods produced, the number and size of distribution of sellers (companies) in the industry, the number and size of buyer distribution, product differentiation, and the ease of entering in the industry. So the industrial structure can determine the growth of an industry.

It is Simons (2003), Ohno and Imaoka (2004), Suslova and Volchkova (2007) and Greasley and Oxley (2007), which prove empirically the role of industrial structures in influencing industrial growth. According to them the industrial structure has a positive effect on industrial growth. The industrial structure reflects how much the outup of a particular industry is in the entire industry's total output. The greater the output share of certain industries shows the increasing growth of the industry in question. Mundradjat Kuncoro (2008) said that industrial growth will not be separated from its industrial structure, if the industry structure is firmly demonstrated by its large (relative) output contribution to total industrial output, industrial growth has an increasing tendency as well.

The impact of the supply of physical capital (capital) on industrial growth can be traced from the opinion of Ohno and Imaoka (2004), which says that the supply of physical capital (capital) will positively correlate with industrial growth. The same thing can also be seen also in the results of empirical studies of Athukorala and Jayasuriya (2004), Dutta and Ahmed (2006), Hirway and Shah (2006), Suslova and Volchkova (2007) and Greasley and Oxley (2007), which prove empirically about the positive influence of capital (capital) supply on industrial growth. Quality and effective workforce is a factor that can drive 
increased work productivity and industrial output produced so as to encourage industrial growth. Conversely, when the quality of labor is low, unproductive and not optimal in producing output, the amount of industrial output produced will decrease, so that it can affect industrial growth. Ippey (2001), Simons (2003) and Athukorala and Jayasuriya (2004) empirically about the positive influence of labor (total) on industrial growth. While Dutta and Ahmed (2006) and Hirway and Shah (2006), which prove empirically about the negative influence of labor (total) on industrial growth.

\section{Conclusions}

The era of globalization and economic liberalization has brought renewal that is very fast and has a broad impact on the economy the most felt impact is the increasingly intense competition in the industrial sector. To build the industrial sector so that it is able to develop in the arena of competition such as today and at the same time make it the driving force of the national economy in the future, the industrial sector needs to have high competitiveness in terms of added value and productivity along the production value chain. Competitiveness is the ability of companies and industries to generate income factors and employment factors that are relatively high and sustainable to face international competition. Continuously increasing industrial competitiveness can form a strong economic foundation in the form of macroeconomic stability, a healthy business climate and investment. International competition is a new perspective for all countries so that the focus of future industrial development strategies is to build the competitiveness of sustainable manufacturing industries in international markets. Sustainable competitiveness lies in the effort to mobilize and organize all potential productive resources to produce innovative products that are cheaper, better, more easily obtained in order to meet market needs and demands.

\section{References}

1. Araujo, J., Esteves, F.F. (1999). Policy Making for Industrial Competitiveness in Portugal: Patterns of Change in a Traditional Bureaucracy. Article. March 1999. Jakarta.

2. Aswicahyono and Hill, H. (2004). Industrial Transformation: Meanings and Challenges. CSIS.

3. Athukorala, P.-C. and Jayasuriya, S. (2004). Complementarity of Trade and FDI Liberalization in Industrial Growth: Lessons from Sri Lanka. ASARC Working Paper 2004. pp. 1 - 28.

4. Central Bureau of Statistics (2004). Incremental Capital Output Ratio of the Manufacturing Industry Sector in 1990-2002. Jakarta.

5. Central Bureau of Statistics (2007). Development of Large and Medium Industrial Production Index 2003-2007. Jakarta.

6. Bell, R.-L. \& Westphal (1984). Industrial Economics and Organization: Theory and Evidence, 2nd Edition, Oxford University Press, Oxford.

7. Berg, H. Van Den (2001). Economic Growth and Development. McGraw Hill International Edition.

8. Besanko, D., Dranon, D., and Shanley, M. (1996). Economic Of Strategic. John Wiley and Sons, Inc. The International Edition.

9. Best, R. J. (1990). Marketing Based Management. 2nd edition. Prentice Hall

10.Braun, M., Briones, I., and Johnson, C. (2007). Competitiveness and Industrial Growth in Latin America. IMF Staff Papers, 41 (1): 1-29.

11.Breschi, S. and Palma, D. (2001). Spatial Patterns of Innovation and Trade Competitiveness The Case of Italy. Working Papers Libero Istituto Universitario C. Cattaneo. October 2001. pp. 1 - 19.

12.Carunia, et al. (2000). Indonesian Economic Structure and Performance after 50 Years of Independent Indonesia. Jurnal Ekonomi UII, Vol. 7, pp. 2-14.

13.Case and Fair (1999). Principles of Macroeconomics. Fifth Edition. PT INDEKS Jakarta.

14.Chacholiades, Miltiades, 1990, International Economics, Mc.Graw Hill Publishing Company

15.Church, J., and Ware, R. (2000). Industrial Organization: A Strategic Approach. McGraw-Hill Companies.Inc. USA.

16.Cole (1998). Concentration in Indonesian Manufacturing Period 1975-1993. BIES, Vol. 35 No. 1. 
17.Cooper, C. (1995). Technology, Manufactured Exports, and Competitiveness. Discussion Paper Series of the United Nations University. Vol. 9513. December 1995. pp. 1 - 48.

18.Cravens, D. W. (1996). Strategic Marketing. Fourth edition. Volume I. Erlangga. Jakarta.

19.Darmansyah (1986). Efforts to Satisfy Customers to Become Loyal, Journal of Economics and Business, Faculty of Atmajaya Economics. Jakarta.

20.Ministry of Industry (2008). Industry Sector Progress Report 2005-2007. Jakarta.

21.Dhanani (2000). Economy of Developing Countries and Agribusiness Enterprises, Grafindo. Jogyakarta:

22.Dong-Sung, C. (2000). From Adam Smith to Michael Porter: Evolution of Competitiveness Theory. First Edition, World Scientific Publishing Co. Pte. Ltd. Singapore.

23.Drejer, I. (1998). Technological Interdependence in the Danish Economy-A Comparison of Methods for Identifying Knowledge Flows. IKE Group and DRUID Department of Business Studied Aalborg University.

24.Dunford, M., Louri, H., and Rosenstock, M. (2000). Competition, Competitiveness, and Enterprise Policies. www.ssrn.com

25.Dutta, D., Nasiruddin, A. (2006). Trade Liberalisation and Industrial Growth in Pakistan: A Cointegration Analysis. IMF Staff Papers, 45 (2): 236-68.

26.Ernst, D. (2006). The Complexy and Internationalization of Innovation: The Root Causes. Article, United Nations, New York and Geneva.

27.Etzel, M. J., Walker, B. J. (1997). Marketing. $11^{\text {st }}$ Edition. McGraw-Hill Companies, Inc. North America.

28.Fagerberg, J., Knell, M., and Srholec, M. (2004). The Competitiveness of Nations: Industrial Growth in the ECE Region. Discussion Papers No. 221, Centre for Technology, Innovation and Culture, University of Oslo.

29.Faisal, A. (1994). Consumer Behavior. Triganda. Bandung.

30.Godin, B. (2004). The Obsession for Competitiveness and Its Impact on Statistics: The Construction of High Technology Indicators. Working Paper Number: 25, September 2004.

31.Greaker, M. (2004). Industrial Competitiveness and Diffusion of New Pollution Abatement Technology: A New Look at The Porter Hypothessis. Discussion Papers No. 371, Statistics Norway, Research Department. March 2004.

32.Greasley, D. and Oxley, L. (2007). Competitiveness and British Industrial Growth. The Manchester School Vol. LXV No. 2, March 2007. pp. 192-212.

33.Grossman, P. and Helpman, R.A. (1993). Hyper Competition: Managing the Dynamics of Strategic Maneuvering. The Free Press.

34.Gujarati, D. (2003). Basic Economitrics. International Student Edition MC Graw Hill International Book Company. New York.

35.Hadi, S. (1998). Indonesian Industrial Competitiveness in PAJ, Indonesian Industrial Competitiveness. Jakarta. German Alumni Association (PAJ).

36. Hamsar, L. (2006). Agribusiness and Other Business Import Exports in National Economic Development, Jakarta.

37. Hasibuan, N.(1993). Industrial Economy: Competition, Monopoly and Regulation. LP3ES. Jakarta.

38. Hasibuan, N. (1993). Market Structure and Conglomeration in Indonesia, Indonesia's economic and political liberalization action agenda, PPM FE UII and PT. Tiara Wacana, Yogyakarta, 169-194.

39. Hendra, H. (2002). International Economy and Economic Globalization. Ghalia Indonesia. Jakarta.

40.Hertati, L. (2015). Internal Control and Ethics Of Quality Management System Accounting Information And Implications On The Quality Of Accounting Information Management: Proposing A Research Framework. International Journal of Economics, Commerce and Management United Kingdom Vol. III, Issue 6, June 2015 Licensed under Creative Common Page 902 http://ijecm.co.uk/ ISSN 23480386

41.Hertati, L. (2015). Research Article Total Quality Management as Technics on Strategic Management Accounting. International Journal of Recent Advances in Multidisciplinary Research. Vol. 02, Issue 11, pp.0942-0949, November. 
42. Hertati, L. (2016). Just In Time, Value Chain, Total Quality Management, Part Of Technical Strategic Management Accounting. International Journal Of Scientific \& Technology Research Volume 5, Issue 04, April 2016 ISSN 2277-8616.

43. Hertati, L. (2015). Competence of Human Resources, the Benefits of Information Technology on Value of Financial Reporting in Indonesia. Research Journal of Finance and Accounting www.iiste.org.ISSN 2222-1697 (Paper) ISSN 2222-2847 (Online) Vol.6, No.8, 2015

44.Hertati, L. (2015). Impact Of Uncertainty Of Environment And Organizational Cultural On Accounting Information System Management And Implications For Managerial Performance Proposing A Conceptual Framework. International Journal of Economics, Commerce and Management United Kingdom Vol. III, Issue 12, December 2015.Licensed under Creative Common Page 455 http://ijecm.co.uk/ ISSN 2348 0386.

45. Hill (1997). Entry, Exit, and Level of Concentration in Manufacturing Industry in Indonesia, 19951997. Indonesian Journal of Economics and Business, Vol. 17 No. I.

46. Hirway, I. and Shah, A. (2006). Industrial Growth and Regional Linkages: A Study of Manufacture Industry in Saurashtra, Gujarat India. Quarterly Journal of Economics, LXX: 65-94.

47.Hsiao, C. (2003). Analysis of Data Panels. Cambridge University Press. Cambridge.

48.Ichary, S. (2008). Globalization and Scientific Revolution in the Diversity of Humanity, Culture and Value. Unpad Press.

49.Intriligator, B., and Hsiao (1996). Mathematical Optimization and Economic Theory. Prantice-Hall Inc. Englewood Cliffs. New York.

50.Ippey, Y. (2001). Industrial Growth and competitiveness of Products in Japan. The Developing Economies, Vol. 31. Number 4, pp. 38 - 65.

51.Irsad, A. (2002). Determinants of Competitiveness of Indonesian Export Products. Innovation Vol.4 / XVII / August 2005.

52.Lengyel, I. (2003). Economic Growth and Competitiveness of Hungarian Regions. Discussion Papers No. 354, Department of Regional and Applied Economics, Faculty of Economics. University of Szeged Hungary.

53.Lubis (2004). Cost of Distribution of Industrial Commodities in Indonesia. Manage, No. 14 / II / 97

54.Khalil, M. T. (2000). Management of Technology. The Key to Competitiveness and Wealth Creation. McGraw Hill.

55.Kim (1999). Industrial Organization: An Analysis of Competitive Market. Prentice Hall

56.Kotler, P., Jatusripitak, S., Maissincee, S. (1997). The Marketing of Nations. The Free Press, New York.

57.Krugman, P.R., Obstfeld, M. (1993). Ekonomi Internasional: Teori dan Kebijakan. Edisi Kedua. PT RajaGrafindo Persada. Jakarta.

58.Kuntz, D. L. and Clow, K.E. (1998). Service Marketing. John Wiley \& Sons, 605 Third Avenue. New York.

59.Macrae, C. and Co-Workwers of the World Net Work Branding Class (1996). The Brand Caracterization Handbook: How to Brand Organizing Learn, Living Script. Addison-Wesly Publishing Company. Eidenburg Gate.

60.Mankiw, N. G. (2000). Macroeconomic Theory. Fourth edition. Erlangga. Jakarta.

61.Marks (1999). Does the Market Structure matter? : New Evidence Using Exogenous Market Structure, Site Working Paper 130.

62. Marzabal, O. R. (2004). Competitiveness and Regional Growth in the European Union: Disparities in Labor Cost. University of Santiago de Compostela. Spain.

63.McCawley (1979). Industry Structure, Market Rivalry, and Public Policy. Journal of Law and Economics, Vol 16, P. 1-9.

64.Meier, G. (1999). Capital and Development. Asian Economic Journal, Publishers Oxford UK. Boston. USA.

65.Mendenhall, W. \& Sincich, T. (2003). A Second Course in Statistics Regression Analysis. Sixth Edition. USA: Pearson Education, Inc. 
66.Mulatu, A., and Raymond J.G.M. Florax, and C. A.A.M. Withagen (2001). Environment Regulation and Competitiveness. Tinbergen Institute Discussion Paper. Vol. 3 Number: 039 April 2001. pp. 1 - 37.

67.Muhammad, A.A., Faisal H. Basri, Ikhsan, M. (1995). Identification of Export Commodities that Have Comparative Advantages and Factors that Influence the Case of Indonesia. FEUI. Jakarta.

68.Ministry of Research and Technology RI. (2004). Vision of Science and Technology 2025. Jakarta.

69.Nachrowi, D. N. and Usman, H. (2008). Popular and Practical Approach, Econometrics for Economic and Financial Analysis. Jakarta: Institute of Publishers of the Faculty of Economics, University of Indonesia.

70.Narula, R. (2006). Knowledge Creation and Why it Matters for Development: The Role of TNCs. Article. United Nations. New York and Geneva.

71.Narayana (2004). Determinants of Competitiveness of Small-Scale Industries in India. The Journal of Business in Developing Nations. Volume 8 (2004). pp. 93-142.

72.Nicholson, W. (1995). Microeconomic Theory: Basic Principles and Development. second edition. PT RajaGrafindo Persada. Jakarta.

73.Ohno, K. and Imaoka, H. (2004). The Experience of Dual Industrial Growth: Korea and Taiwan. The Developing Economies, Vol. 34. Number 2, pp. 310-234.

74.Pangestu, M. (2005). The Evolution of Competition Policy in Indonesia. Review of Industrial Organization, Kluwer Academic.

75.Prawiro (1998). The Determinants of Entry: A Study of the Canadian Manufacturing Industries. The Review of Economics and Statistics, Vol. 56.

76.Pearce, R. (2006). The Globalization of R \& D: Key Features and the Role of TNCs. Article. United Nations. New York and Geneva. 2006

77.Perez, C. (2001). Technological Change and Opportunities for Development as a Moving Target. Cepal Review 75. December.

78.Porter, M. E.(1990). The Competitive Advantage of Nations. The Free Press. New York.

79.Porter, M. E. (1994). Competitive Advantage. The Free Press. New York.

80.Ray (2003). Relation of Profit to Industry Concentration: American Manufacturing 1996-2000. Quarterly Journal of Economics.

81.Reddy, P. (2006). R \& D Related FDI in Developing Countries: Implications for Host Countries. Article. United Nations New York and Geneva.

82.Reiljan, J., and Hinrikus, M. and Ivanov. A. (2000). Key Issues In Defining and Analyzing The Competitiveness of a Country. Tartu University Press Working Paper. Number: 3974, April 2000. pp. 1 - 59.

83.Romer (2006). Advanced Macroeconomics. Singapore: McGraw-Hill International Edition. Economic Series.

84.Sadono, S. (1985). Economic Development: Process, Problem, and Basic Wisdom. LPFE University of Indonesia. Jakarta.

85.Salvatore, D. (1995). International Economics. Fifth Edition Prentice Hall International, Inc. New Jersey.

86.Salvatore, D. (1997). International Economy. (Translation). fifth edition. Prentice Hall International, Inc. A Simon \& Schuster Company.

87.Sandee, A. \& Sulandjani (2000). The Dynamic of UK Industrial Concentration 1993-1997. Working Paper, Department of Economics, Loughborough University.

88.Sanjaya, L. (2003). Reinventing Industrial Strategy: The Role of Gomernment Policy in Building Industrial Competitiveness. QEH Working Paper Series. Number: 111. October 2003, pp. 1 - 35.

89.Schiller R., Bradley (1997). The Economic Today. Seventh Edition. The McGraw Hill Companies Inc.

90.Now, U. (2000). Research Methods for Business. 3th Edition. New York: John Willey and Sons Inc.

91.Silva, M. R. and Rodrigues, H. (2005). Competitiveness and Public Private Partnerships towards a More Decentralized Policy. FEP Working Papers Research - Work in Progress. Number: 171. April 2005.

92.Simons, L. K. (2003). Industrial Growth and Competition. International Economic Review , 44:102935.

93.Soesastro \& Atje (2005). The Impact of Real Sector Policy on the Structure and Performance of Indonesia's Industrial Structure 1980-1994. Manage No. 11 / V / 96, h. 34 - 52. 
94.Sripaipan (1990). On the Simultaneity between Market Concentration and Profitability: The Case of a small - open developing country, International Economic Journal Vol. 7 number 1

95.Sritua, A. (1993). Economic Research Methodology. University of Indonesia Publisher. Jakarta.

96.Stanton, W. J. (1991). Fundamental of Marketing. 5th Edition. Singapore. Mc. Graw Hill.

97.Sukirno (2000). Customers Key to Success. Main Partner. Jakarta.

98.Suryono (1999). Efforts to Increase Regional Competitiveness. Kadin Indonesia - Jetro.

99.Suslova, E. and Volchkova, N. (2007). Capital, Industrial Growth and Industrial Structure. IMF Staff Papers, 45 (2): 236-68.

100. Syahril, S. (2002). Role of Monetary and Banking Policy in Overcoming the Economic Crisis in Indonesia, Paper on Public Lecture at Padjadjaran University, May 31, 2002, Bandung:

101. Thee (1988). Concentration in Indonesia Manufacturing. BIES Vol. 23. No. 23, pp. 71-00.

102. Thee \& Pangestu (1998). Our National Car and Industrial Strategy, CIDES AFKAR Journal Vol. 1 , No. 1 , h. 52-84.

103. Thurow (1992). Head to Head: The Coming Economic Battle among Japan, Europe, and America. Foreign Affairs. August 1992. pp. 189 - 192.

104. Timmer (2000). Industrial Organization, Second Edition, Prentice Hall International, New Jersey-USA.

105. Todaro. M. P. (2000). Economic Development in the Third World. Erlangga Publisher. Jakarta.

106. Tucker, B. I. (1998). Survey of Economics. 2nd Edition. South Western College. Ohio. USA:

107. Tulus, T. (2001). Price and Production of Large-Scale Enterprise, American Economic Review, Supplement, pp. 61-74

108. Tulus, T. (2001). Industrialization in Developing Countries. The case of Indonesia. Ghalia Indonesia. Jakarta.

109. Tulus, T. (2007). Economic Transformation in Indonesia: Empirical Theories \& Discovery. Salemba Empat. Yakarta.

110. United Nations Industrial Development Organization (UNIDO) (2003). Investment and Technology Policies for Competitiveness. New York and Geneva.

111. Yudo, S. and Endang (1993). Human Resource Development. CV publisher Izuta Gempita. Jakarta.

112. Widjaya, A. (1999). Economic Crisis in National and Regional Contexts. Indonesian Society Journal No. 1 Vol. XXV. Jakarta: May, pp. 20 -47.

113. World Bank (1996). World Development Indicators 1996. Washington, D.C.

114. World Bank (1997). World Development Indicators 1997. Washington, D.C.

115. World Human Development Report (2001). New York and Geneva. 